\title{
Computational Study of the Heat Ventilation on The Attics of Buginese Houses
}

\author{
Sahabuddin Latif ${ }^{1}$, Baharuddin Hamzah ${ }^{2}$, Ramli Rahim ${ }^{3}$, Rosady Mulyadi ${ }^{4}$, Irnawaty Idrus ${ }^{5}$ \\ ${ }^{1,5}$ Departement of Architecture, Faculty of Engineering, Universitas Muhammadiyah \\ Makassar, Indonesia. 90221 \\ ${ }^{2,3,4}$ Departement of Architecture, Faculty of Engineering, Universitas Hasanuddin Makassar, \\ Indonesia. 92119 \\ \{sahabuddin.latief@unismuh.ac.id', baharsyah@unhas.ac.id²,yb8bri@yahoo.com³, \\ rosady@unhas.ac.id ${ }^{4}$,irnawatyiqbal@yahoo.co.id $\left.{ }^{5}\right\}$
}

\begin{abstract}
Numerical investigation of heat ventilation on the traditional house attic of Buginese in a hot and humid tropical climate was carried out using computational fluid dynamics models. The Navier-Stokes (RANS) modeling approach is used for numerical investigations. Determined the breakdown of steady-state conditions by using SolidWorks Flow Simulation software. Based on various flow simulations, numerical results obtained for temperature distribution, airflow patterns, indoor turbulence characteristics, Dynamic pressure, Density, and Turbulent Viscosity are presented. Using numerical results, it is known that the stack effect lowers the Attic temperature by increasing the airflow in it.
\end{abstract}

Keywords: Thermal Comfort, Attic Thermal, Chimney Effect, CFD Simulation.

\section{Introduction}

The condition of Indonesia's hot and humid tropical climate causes problems of heat accumulation in the attic and inside the built-in residential space. To overcome this problem, residents use a mechanical air conditioning unit to reduce indoor temperature $[1,2]$. Some researchers see the potential difference in attic temperature and the environment in hot and humid tropical climates can support the effect of chimney for cooling the room for free [3-6].

The potential for natural cooling in triangular lofts in tropical climates has attracted many researchers. The utilization of solar energy is one of the main strategies used to provide renewable energy buildings. Chimney effect strategy to conduct an in-depth study of this potential requires high accuracy in its calculations. In the analysis, there are many methods used to obtain maximum benefits, but of the many methods used, the methods of experimentation, field measurements, and computer simulations are the most widely used [6-10].

This study aims to investigate the numerical heat ventilation in the attic of traditional Buginese houses in a hot and humid tropical climate. Investigate the possibility of technical analysis of several strategies to improve the passive natural ventilation system model using computer simulation methods. When evaluating the effectiveness of designs in attic spaces, much comprehensive building simulation software are commonly used, such as EnergyPlus, ESP-r, Transys, Ansys [11-14]. A Computational Fluid Dynamic (CFD) software that is SolidWorks Flow Simulation (SWFS) that has operational ease and is quite accurate still rarely 
used for attic investigation as once did on the roof of a house in the United States [12]. In Indonesia, several recent studies analyzing classroom air flow using SWFS have been carried out $[15,16]$.

Based on the literature review, it is clear that research on the potential for passive cooling in buildings has generated the interest of researchers throughout the world, especially using computer analysis. However, recent research is still lacking using SWFS software to investigate airflow on triangular roofs in hot and humid climates. More specifically in Indonesia, almost no studies have concentrated on passive cooling studies in attics, so weather studies on attics need to be done. The purpose of this study was to report thermal conditions in attic of traditional Buginese houses using SWFS analysis.

\section{Material and Methods}

\subsection{Simulation Software}

SolidWorks Simulation (version 2016) is used to simulate airflow and heat transfer. This software was previously validated in the literature $[12,15,17]$. The air properties are assumed to be constant, the air flow in the cavity is considered stable and a pressure based solver is used. The CFD model used in this work is based on the Reynolds-Averaged Navier Stokes (RANS) equation. Continuity, momentum, and energy equations are solved by the turbulence model RNG k - $\varepsilon$ (2 equations), which is recommended for building simulations $[11,12,15]$.

\subsection{Geometry}

Picture. 1 presents a 2-dimensional cross-section attic prototype with height $h=0.3 \mathrm{~m}$, and width $1=0.60 \mathrm{~m}$. In this system, two holes are placed at the base of the attic and one hole at the top of the attic. The first and second holes are located at the bottom of the attic each $0.01 \mathrm{~m}$, placed at a distance of $0.01 \mathrm{~m}$ from the horizontal field of the attic, used for induction of air flow from the environment to the attic. The third hole, placed at a distance $\mathrm{h}=0.3 \mathrm{~m}$ from the base on the attic, allows the evacuation of air from the interior space to the top of the attic. 


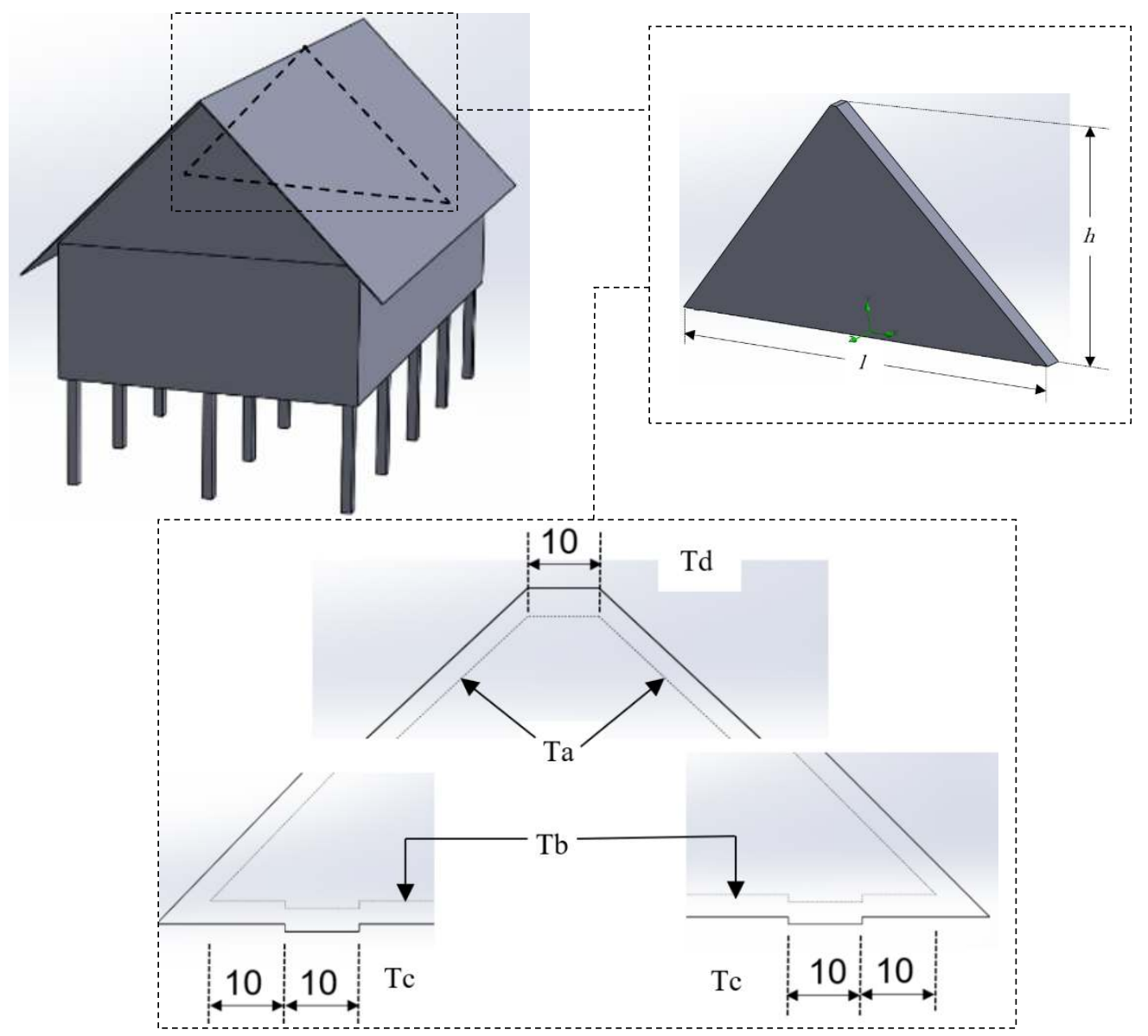

Fig. 1. 3D view of the building and detail of the attic model

\subsection{Numerical Model}

The mathematical description of this model is based on the Navier-Stokes equation, which is a law that refers to mass darkness, momentum, and energy conservation, [11, 12] given as follows:

$$
\begin{gathered}
\frac{\partial u}{\partial x}+\frac{\partial v}{\partial y}+\frac{\partial w}{\partial z} \\
\frac{\partial u}{\partial t}+\frac{\partial u u}{\partial x}+\frac{\partial u v}{\partial y}+\frac{\partial u w}{\partial z}=-\frac{1}{\rho} \frac{\partial p}{\partial x}+\frac{1}{\rho} \frac{\partial \tau_{x x}}{\partial x}+\frac{1}{\rho} \frac{\partial \tau_{y x}}{\partial y}+\frac{1}{\rho} \frac{\partial \tau_{z x}}{\partial z}+g_{x} \\
\frac{\partial v}{\partial t}+\frac{\partial v u}{\partial x}+\frac{\partial v v}{\partial y}+\frac{\partial v w}{\partial z}=-\frac{1}{\rho} \frac{\partial p}{\partial y}+\frac{1}{\rho} \frac{\partial \tau_{x y}}{\partial x}+\frac{1}{\rho} \frac{\partial \tau_{y y}}{\partial y}+\frac{1}{\rho} \frac{\partial \tau_{z y}}{\partial z}+g_{y} \\
\frac{\partial w}{\partial t}+\frac{\partial w u}{\partial x}+\frac{\partial w v}{\partial y}+\frac{\partial w w}{\partial z}=-\frac{1}{\rho} \frac{\partial p}{\partial z}+\frac{1}{\rho} \frac{\partial \tau_{x z}}{\partial x}+\frac{1}{\rho} \frac{\partial \tau_{y z}}{\partial y}+\frac{1}{\rho} \frac{\partial \tau_{z z}}{\partial z}+g_{z}
\end{gathered}
$$




\section{Results and Discussion}

As presented in Figure 1, a traditional Bugis house attic is defined in a 2-dimensional calculation, considered visualizing, air temperature, air average velocity, dynamic pressure, density, turbulent energy, and turbulent viscosity under conditions this is steady flow because the air is not compressed.

There are two simulation models that are compared, namely: 1) Showing the condition of the air temperature distribution in Attic when there is almost no air exchange circulation or no ventilation, after which the roof surface heat limit conditions are set in $\mathrm{T}_{\mathrm{a}}=46.3{ }^{\circ} \mathrm{C}$, attic base $\mathrm{T}_{\mathrm{b}}=34.9^{\circ} \mathrm{C}$ (MODEL-1). 2) the simulation model is governed by boundary conditions, in two holes at the bottom of the lot where airflow is regulated by boundary codition static pressure with ambient temperature $\mathrm{T}_{\mathrm{c}}=32.1^{\circ} \mathrm{C}$. A rooftop hole was determined by boundary condition environment pressure $\mathrm{T}_{\mathrm{d}}=32.2^{\circ} \mathrm{C}(\mathrm{MODEL}-2)$.

\subsection{Temperature}

Figure 2 shows the temperature distribution in the fields specified for the two ventilation models. Figure $2 \mathrm{a}$, it has been observed that the temperature is regulated by attic boundary conditions without ventilation (MODEL-1) shows the highest temperature $\mathrm{T}=64.3{ }^{\circ} \mathrm{C}$ with an average $\mathrm{T}=53.9^{\circ} \mathrm{C}$, attic heat distribution on the roof surface and higher attic upper chamber, to the lower bottom Figure $2 \mathrm{~b}$ shows the air temperature distribution in the attic with (MODEL2) a decrease in temperature, that is, the average $\mathrm{T}=40.1^{\circ} \mathrm{C}$, the distribution of hot air on the roof surface gets cooler and reaches the lowest value in the attic hole due to air infiltration.

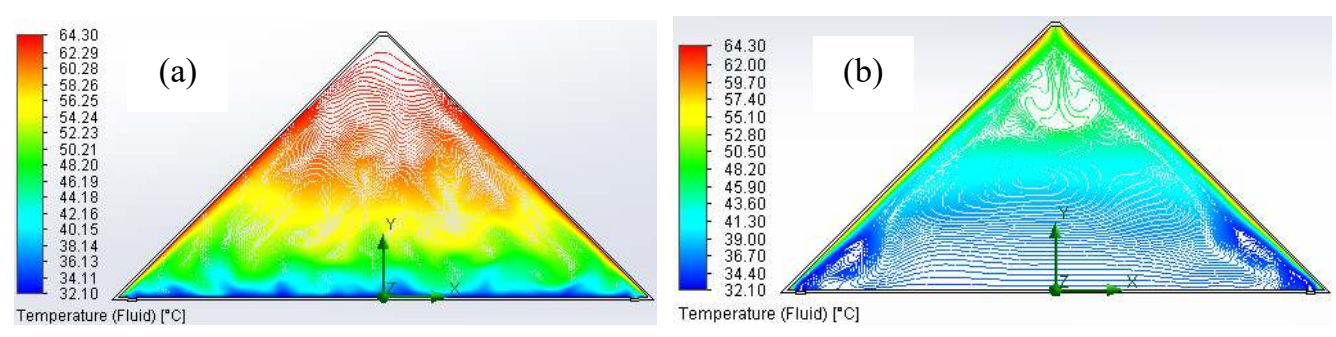

Fig. 2. Distribution of the temperature field.

\subsection{Velocity}

Figure 3 shows the velocity field distribution in the field for two ventilation models. Based on these results, figure 3a explains that the average velocity in the attic space (MODEL-1), which is $0.017 \mathrm{~m} / \mathrm{s}$, is spread unevenly to the bottom of the attic, heat fluctuations occur so that the maximum air velocity can reach $\mathrm{V}=0.12 \mathrm{~m} / \mathrm{s}$. Figure $3 \mathrm{~b}$ shows the air flow distribution (MODEL-2) that there is air induction from the direction of the hole on the attic base which flows along the roof surface which finally exits at the top of the attic with maximum $\mathrm{V}=0.4$ $\mathrm{m} / \mathrm{s}$ occurring at the top of the attic. This attic with a zinc roof can hold great heat energy during the day. In particular, the area of the middle of the attic zone is characterized by a low-velocity value that does not exceed $\mathrm{V}=0.05 \mathrm{~m} / \mathrm{s}$ 

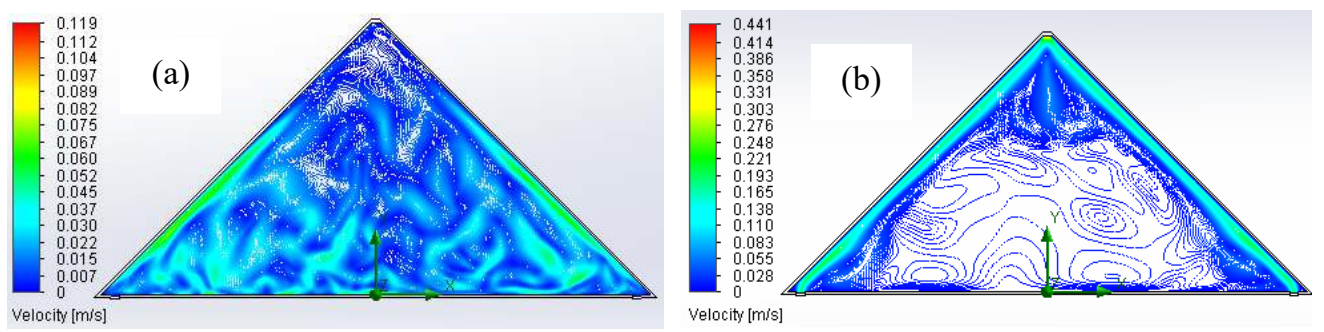

Fig. 3. Distribution of the velocity field.

\subsection{Dynamic pressure}

Figure 4 shows the dynamic pressure on the cut load. Based on these results, we find the distribution characteristics of the maximum dynamic pressure values almost evenly distributed throughout the attic area, especially the area around the roof surface and the attic base, in the Model-1 simulation (Fig. 4a). However, Model-2 simulations show a dynamic pressure distribution higher than only concentrated in the discharge area located between the inlet and roof wall to the attic peak (Fig. 4b). Outside this zone, the dynamic pressure decreases before rising in the exit hole at the top of the attic.
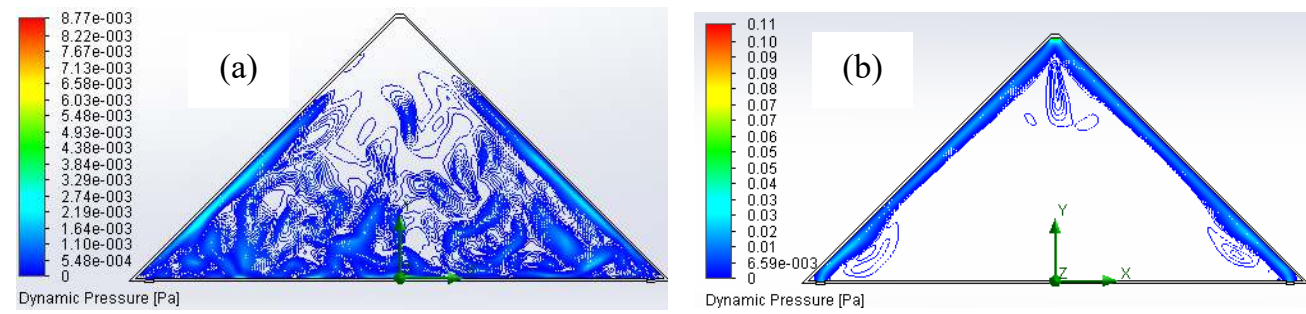

Fig. 4. Distribution of the dynamic pressure field.

\subsection{Density}

Figure 5 shows the density in the specified cutting plane. Based on these results, we find the characteristics of higher density zones on the surface of the attic base in the Model-1 simulation (Fig. 5a). For the Model-2 simulation (Fig. 5b), higher densities occur in the discharge area located between the inlet at the bottom of the attic and the left and right roof walls, which continue to decrease to the top of the attic. 


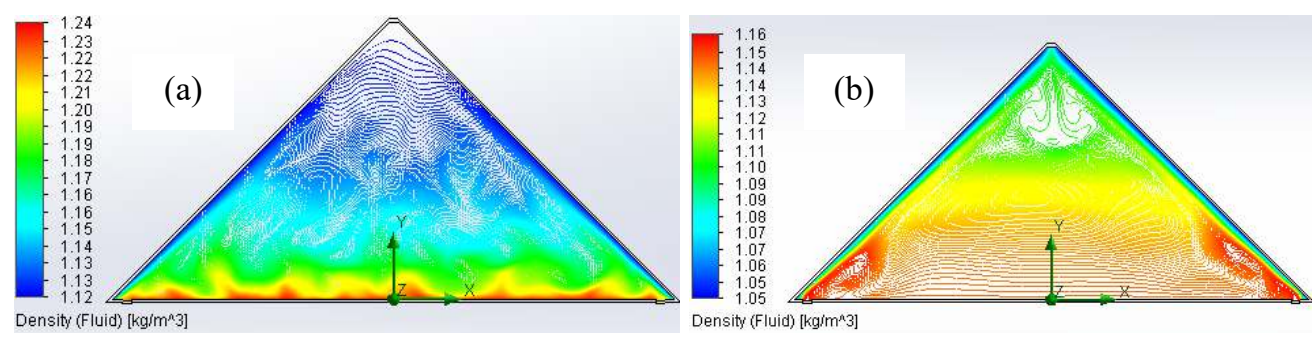

Fig. 5. Distribution of the density field.

\subsection{Turbulent Energy}

Figure 6 shows the turbulent energy in the cut plane. Based on these results, we find the characteristics of the turbulent energy zone around the roof surface in the attic section of the Model-1 simulation. For the Model-2 simulation (Fig. 6b), the turbulent distribution of energy is only around the roof surface in the attic, but the value is higher than the Model-1 simulation (Fig. 6a).

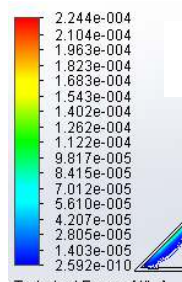

(a)

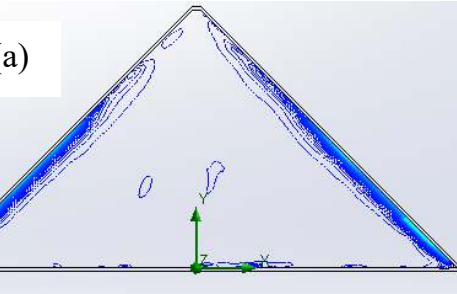

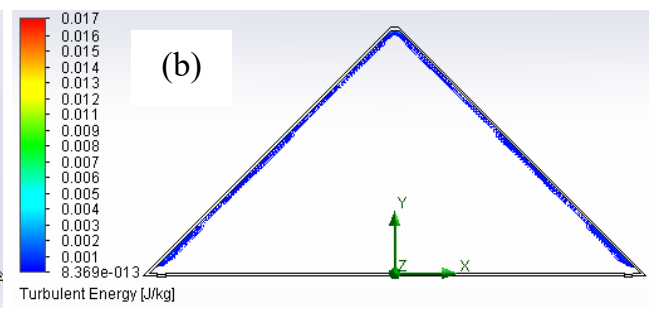

Fig. 6. Distribution of the Turbulent Energy field.

\subsection{Turbulent Viscosity}

Figure 7 shows the turbulent viscosity in the cutting plane. Based on these results, it has been observed that turbulent viscosity is low in the hole inlet located at the bottom of the attic to rise to the top of the attic. High turbulent viscosity occurs in the middle of the attic in a Model1 simulation.

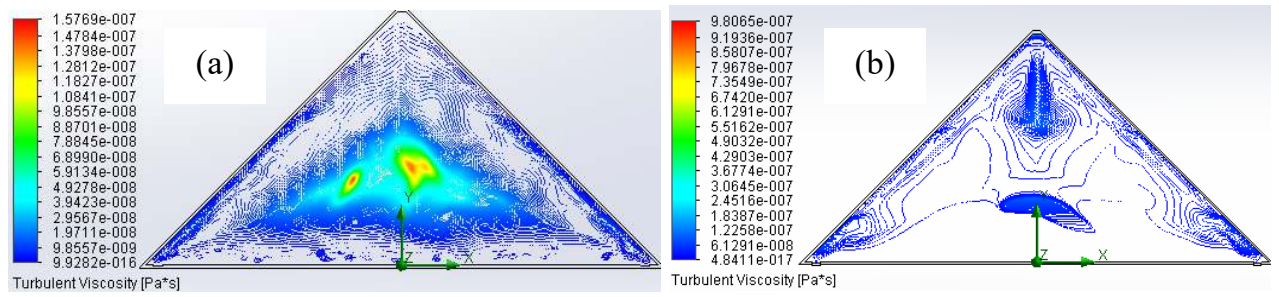

Fig. 7. Distribution of the turbulent viscosity field. 


\section{Conclusion}

In this paper, we have developed a computational study using the SolidWorks Flow Simulation software from heat ventilation in the attic of a traditional Buginese house in a hot and humid tropical climate using the chimney effect of the sun's heat potential. The Buginese house triangular roof can store large heat stocks during the day throughout the year. This solution can improve weather conditions in the attic by modifying how to increase the flow of air in it, by utilizing the stack effect that occurs due to differences in attic temperature and the environment. In this study, the inlet area was made of two holes at the base of the attic. This flow creates two circulation zones on the inner surface of the roof which then empties into the top of the attic. By approaching the hole located at the top of the attic, the speed is slightly increased. These results present a very interesting idea for building thermal energy using a solar terrace system. In the future, we propose to work on a method that saves energy to assume continuous heating with zero energy.

\section{Acknowledgements}

This research was funded by the University Muhammadiyah of Makassar Research and Community Service Institute, with contract No. 0105/KONTR- PENL/PENGABD/IV/1439/ 2018, dated April 5, 2018. Therefore, The author thanked all parties who have helped in completing this research, starting from the proposal stage, survey, analysis and discussion of the results of the research. This research was part of the first author doctoral program research at the Department of Architecture at the Hasanuddin University of Makassar Indonesia.

\section{References}

[1] Chantawong, P: Field-measured Performance of Lightweight Roof Chimney Integrated with DC fans. Energy Procedia. Vol. 138, pp. 44-49. doi: 10.1016/j.egypro.2017.10.044 (2017)

[2] Hamzah, B. Kusno, A. Mulyadi, R: Design of energy efficient and thermally comfortable air-conditioned university classrooms in the tropics. International Journal of Sustainable Energy. Vol. 37, pp. 1-16. doi: 10.1080/14786451.2018.1539394 (2018)

[3] Tan, AYK. Wong, NH: Influences of ambient air speed and internal heat load on the performance of solar chimney in the tropics. Solar Energy. Vol. 102, pp. 116-125. doi: 10.1016/j.solener.2014.01.023 (2014)

[4] Al-Obaidi, KM. Ismail, M. Rahman, AMA: Passive cooling techniques through reflective and radiative roofs in tropical houses in Southeast Asia: A literature review. Frontiers of Architectural Research. Vol. 3, pp. 283-297. doi: 10.1016/j.foar.2014.06.002 (2014)

[5] Al-Obaidi, KM. Ismail, M. Rahman, AMA: Design and performance of a novel innovative roofing system for tropical landed houses. Energy Conversion and Management. Vol. 85, pp. 488-504. doi: 10.1016/j.enconman.2014.05.101 (2014)

[6] Al-Obaidi, KM. Ismail, M. Rahman, AMA: A review of the potential of attic ventilation by passive and active turbine ventilators in tropical Malaysia. Sustainable Cities and Society. Vol. 10, pp. 232-240. doi: 10.1016/j.scs.2013.10.001 (2014) 
[7] Al-Obaidi, KM. Ismail, MA. Abdul Rahman, AMJBSER. Technology: Effective use of hybrid turbine ventilator to improve thermal performance in Malaysian tropical houses. Vol. 37, pp. 755-768. doi: 10.1016/j.scs.2013.10.001 (2016)

[8] Khedari, J. Yimsamerjit, P. Hirunlabh, J: Experimental investigation of free convection in roof solar collector. Building and Environment. Vol. 37, pp. 455-459. doi: (2002)

[9] Puangsombut, W. Hirunlabh, J. Khedari, J. Zeghmati, B. Win, M: Enhancement of natural ventilation rate and attic heat gain reduction of roof solar collector using radiant barrier. Building and Environment. Vol. 42, pp. 2218-2226. doi: (2007)

[10] Ayadi, A. Bouabidi, A. Driss, Z. Abid, MS: Experimental and numerical analysis of the collector roof height effect on the solar chimney performance. Renewable Energy. Vol. 115, pp. 649-662. doi: 10.1016/j.renene.2017.08.099 (2018)

[11] Rodríguez, D: A combination of parabolized Navier-Stokes equations and level-set method for stratified two-phase internal flow. International Journal of Multiphase Flow. Vol. 88, pp. 50-62. doi: 10.1016/j.ijmultiphaseflow.2016.09.014 (2017)

[12] Driss, S. Driss, Z. Kammoun, IK: Computational study and experimental validation of the heat ventilation in a living room with a solar patio system. Energy and Buildings. Vol. 119, pp. 28-40. doi: 10.1016/j.enbuild.2016.03.016 (2016)

[13] Crawley, DB. Lawrie, LK. Winkelmann, FC. Buhl, WF. Huang, YJ. Pedersen, CO. Strand, RK. Liesen, RJ. Fisher, DE. Witte, MJ: EnergyPlus: creating a new-generation building energy simulation program. Energy and buildings. Vol. 33, pp. 319-331. doi: (2001)

[14] Al-janabi, A. Kavgic, M. Mohammadzadeh, A. Azzouz, A: Comparison of EnergyPlus and IES to model a complex university building using three scenarios: Free-floating, ideal air load system, and detailed. Journal of Building Engineering. Vol. 22, pp. 262280. doi: 10.1016/j.jobe.2018.12.022 (2019)

[15] Latif, S. Hamzah, B. Ihsan: Pengaliran Udara untuk Kenyamanan Termal Ruang Kelas dengan Metode Simulasi Computational Fluid Dynamics. Sinektika. Vol. 14, pp. 209216. doi: (2016)

[16] Febrina, D. Hamzah, B. Mulyadi, R: Pengaruh Elemen Fasad Terhadap Laju Pergerakan Aliran Udara Di Ruang Kelas. Jurnal Arsitektur PURWARUPA. Vol. 1, pp. 19-28. doi: (2018)

[17] Korres, DN. Tzivanidis, C. Koronaki, IP. Nitsas, MT: Experimental, numerical and analytical investigation of a U-type evacuated tube collectors' array. Renewable Energy. Vol. 135, pp. 218-231. doi: 10.1016/j.renene.2018.12.003 (2019) 